\title{
The Status Quo and Outlet of Household Ceramic Art Development in China Reflection on the Current Situation and Problems of China Through the Development of Korean Household Ceramic Art
}

\author{
Lan $\mathrm{Yao}^{1, *}$
}

\author{
${ }^{1}$ Shanghai Art \& Design Academy, Shanghai 201800, China \\ *Corresponding author. Email: lanlan95@126.com
}

\begin{abstract}
By comparing the background and development of Korean household ceramic art with the background and current environment of Chinese household ceramic art, this paper considers the current situation and existing problems of the development of Chinese household ceramic art. First, at present, each ceramic producing area is aware of its backward concept, and to balance inheritance and innovation is an urgent issue. Second, since the 1980s, various colleges and universities began to popularize the education system of modern ceramic art, the ideas of which were mainly introduced from the West. Modeling ceramic art was taken as the main means of communication, and the universal education of life ceramic art rarely was involved. Third, the market is not standardized. This paper also gives a certain discussion on the solutions to the existing problems.
\end{abstract}

Keywords: household ceramic art, Korea, research institute, university education, market

\section{INTRODUCTION}

Household ceramic art is a modern ceramic art to improve the taste of the living environment, increase artistry and embody personal aesthetics. It decorates people's living environment and improves people's living quality, such as catering utensils, lamps, flowers and decorative pottery. Although these ceramics are also functional ceramics or practical ceramics, they are very different from general ceramics in the general sense. They have a distinct personality in terms of shape, materials and production technology, and have the language characteristics of modern ceramics.

However, China started late in the modern ceramic art and the start and research of household ceramic art is later than that in the West, Japan, and South Korea. As an old saying goes, jade can be polished by stones from other hills, therefore, the author wants to find the future development and direction of China's household ceramic art through the development and research of Korean household ceramic art.

\section{THE BACKGROUND AND DEVELOPMENT} OF KOREAN HOUSEHOLD CERAMIC ART

It mainly understands the development and maturity of Korean household ceramic art by sorting out the four

CLC number: J527 aspects of the Korean government and research institutions, university education, markets, and Korean household ceramic art potters.

\section{A. Government and research institutions}

In the 1960s, Korea began to establish a ceramics research institute, promote national culture, set up museums, carry out research on traditional tangible culture, and establish the Korea Modeling Culture Research Institute. In the 1970s, national exhibitions, East Asian exhibitions, solo exhibitions and group exhibitions began. Ceramic art groups centered on various universities were established to hold exhibitions. In the 1970s, the ceramics industry was dominated by national exhibitions, East Asian craft exhibitions and folk exhibitions. Newcomers' ceramic art exhibitions and other ceramic art exhibitions have been increasing. The establishment of the Korean Ceramic Artists Association in 1975 promoted the development of Korean ceramic art culture and brought an opportunity for introspection and criticism to the ceramic art world that blindly pursued the concepts of modern Western ceramic art at that time. In the 1980s, Korean ceramics technology developed by leaps and bounds in quality and quantity. Group exhibitions organized by younger artists and planning exhibitions organized by art museums or galleries were more active. In 1981, the National Exhibition ended and was reorganized, breaking the past form and changing the 
operation mode, and the composition of the exhibition brought about changes. In 1986, the craft exhibition was completely separated, and the participation of craft talents increased. Planning exhibitions and hospitality exhibitions have also been developed to convene exhibitions, and general art galleries have also begun to hold arts and crafts exhibitions to expand the concerns of the masses. The Korean ceramic art community once paid attention to modeling ceramic art, and this phenomenon continued until the late 1990s. Under this situation, Lichuan began to use the popularization of life to create the Lichuan Ceramics Festival in 1980s for the comprehensive development of ceramic art. It held annual exhibition of ceramic discount market, ceramic exhibition, selection competition, ceramic ignition demonstration activities, etc. The types of ceramic art exhibitions in the 1990s have increased, emphasizing the return of craftsmanship. In 1994, it organized exhibitions to sort out ceramic art sessions, with the theme of the creative camp drawing contest, product sales, household ceramic art markets, exhibitions and activities focusing on reflection and organization, and the number of individual exhibitions decreased. Since the 20th century, the Gyeonggi do World Ceramic Biennale began to be held in South Korea, making a great contribution to the promotion of Korean ceramic art. In 2000, the establishment of the Lichuan World Ceramic Center, the official Korean Kiln Museum in Guangzhou, and the Lizhou World Life Ceramics Museum brought new vitality to the development of the ceramic industry and the artistic exchange of world ceramic art. Ordinary people also have a new understanding and interest in ceramic art.

\section{B. Popularization of university education}

The focus on the development of pottery education at the university began in the 1850 s. The Department of Ceramics at the Hongik University set up a ceramics major and hired foreign teaching special guidance. In the 1860 s, foreign students returning from abroad began teaching ceramics in the ceramics department. After graduating from Hongik University, students have successively taught ceramics at various universities. In the $1870 \mathrm{~s}$, the ceramics department in universities began to increase. Each university has increased its ceramics major and increased its population. The importance of industrial design has been actively promoted in professional settings. In the 1870 s, the ceramic art department and the kiln industry technology department gradually increased, and the school facilities have become complete. The stability of university education has led to an increase in cuttingedge Korean ceramic artists. In the latter half of the 1870 s, the tendency to accept ceramic art modeling began to increase. The increase in students studying abroad brought changes in the input of new concepts, the tendency of modern modeling was rapidly spreading, some new experiments were made using changes in soil and fire, and new languages began to appear. At that time, young ceramicists from colleges actively collected experimental conceptual ceramics. These methodologies produced rapid changes. This experimental and modeling work didn't review this process, but began to spread, hindering the development of ceramic art. In the 1980s and 1990s, Western art concepts were introduced to ceramic art education. Ceramic art education in colleges became more and more professional, and gradually began to be based on design concepts, modeling theory and artbased teaching method theory. In the latter half of the 1890s, many universities questioned the excessive importance of modern Western ceramic education. The ceramic art students who graduated from the university were made with personal orientation and feeling at the university. It is difficult to get public appreciation. Since the 21st century, universities have begun to target educational reforms, with selective emphasis on modeling, industry and jiggering education as well as traditional education. Universities have also begun independent teaching. The school has established sales channels for students and the market. They feedback market information to the classroom in a timely manner to let students understand the latest development of the market. Students choose their own learning direction according to the needs of the market.

\section{The formation of a mature market}

With the improvement of living standards, the demand for ceramics for daily necessities increases accordingly. The supply of mature raw materials, the popularization of gas kilns, the mechanization of facilities, and the inheritance of ceramics have been actively developed. In the late 1970s and early 1980s, the popularity of small-scale workshops began. It brought expectations to the public at the level of life and culture. A small number of students graduating from university started to establish workshops. The original and interesting design, the affordable price, more sense of hand-made than the manufacturer and the focus on the original use and value of practical crafts laid the foundation for life crafts. In the early 1980s, workshop pottery was a very small part of daily pottery enthusiasts, and no company or store was formed. It can only be sold in the form of some small life stores and intermediaries commissioned by the artists themselves. The potters had no operating funds and they slowly opened special stores and exhibition halls in difficult circumstances. In the middle and late 1980s, low-end and middle-end stores began to increase gradually. It consisted pottery workshops that circulate through branches across the country. In the 1990s, the sales exhibition halls for life crafts were also opened one after another, and the popularity of material dealers and specialty shops gave artists the basis for free activities. The formation of art galleries specializing in selling ceramics brought vitality. Pottery producers of small- 
scale workshops sold on their own or found a cooperative operation of the seller's organization and developed their own designs. The handicrafts that were pushed aside by machine products formed a new process. These crafts also had the possibility of mass production. Efficient operations could see the possibility of mass production. Since the 21 st century, the explosive growth of ceramics for daily use that meets general practicality has led to products with strong personalities getting attention, although these works are not very practical. This reflects the aesthetics of an era, and the demand is changing.

\section{The diversity of creations of Korean household potters}

Korea's current household potters are centered around the three generations of old, middle-aged and young people from technical education. $60-70 \%$ of them are between 20 to 30 years old, and $30 \%$ are between 40 to 50 years old. Most of the potters who have traditionally recreated were from the middle-aged and young people in the 1980s and 1990s. Most of them work as professors in universities, and some work fulltime creations. At present, the number of young potters is increasing. The artist's work highlights the trend of subdivision. There are artists who insist on doing research on light greenish blue and slip casting techniques, and potters who specialize in white porcelain and glazing color. At this stage, diversified methods such as artists who convert craftsmanship and pure art form to the inherent conceptual form appear. Attention is paid to the function to express the traditional expression techniques as the trend of modern gorgeousness or the trend of pure modeling. The style is also diverse. Centering around ceramic artists based on artistry, in the Korean household ceramics field, groups of pottery artists with a strong reinvention of tradition in Korea, pottery artists groups with modernity and design of slip casting, and pottery artists groups with strong modeling have also developed.

\section{EMBARRASSMENT AND WAY OUT - THE DEVELOPMENT AND PRESENT SITUATION OF HOUSEHOLD CERAMIC ART IN CHINA}

China has vast territory and abundant resources all long, with many kilns and various types of ceramics. Richness and diversity are the best explanation for the general trend of Chinese ceramics. However, at present, all ceramic production areas are aware of the lag of their own concepts, and how to inherit and innovate is also an urgent task to be solved.

\section{A. Government and research institutions}

The National Fine Arts Exhibition started in 1949 is the most authoritative art exhibition in China. Until 2009, the 11th National Fine Arts Exhibition began to have an independent exhibition area. In 1989, the China Ceramic Industry Association was established to be responsible for the management of the national ceramic industry. The first China Contemporary Youth Ceramic Biennale was held in Hangzhou in 1998. In April 2003, the Ceramic Research Center of the China Academy of Art was established, dedicated to the creation and theoretical research of Chinese ceramic art. It aims to promote the development of contemporary ceramic art in China and its purpose is to carry out in-depth exploration and research on outstanding works and creative theories in the field of contemporary ceramic art. The Jingdezhen Ceramic Fair started in 2004 and was organized by the Jingdezhen government to display Jingdezhen ceramic products and promote Jingdezhen ceramic culture. In 2011, the Jingdezhen municipal government held the first "Gaoling Cup" Contemporary International Ceramic Art Exhibition, which ended in the second term; the first Hunan (Liling) Ceramic Expo started in 2015; in 2016, the future of the First Household Ceramic Art Exhibition held by Henan Museum is the first exhibition in the sense of independent branch of household ceramic art, which has certain practical significance.

In addition, since the beginning of the 20th century, companies such as Gaochun Ceramics, Guangzhou Hengfu, and Xiaoxing (Lotte) held ceramic design competitions and exhibitions; the Franz Ceramic Design Competition started in 2008, etc. have promoted the spread of ceramic art; the role of Lotte Pottery Workshop, established in Hong Kong in 1985, played a very important role in the publicity and promotion of pottery in China. The "Lotte Pottery Workshop Creative Market" opened in Jingdezhen in 2008 became one of the most important platforms for young entrepreneurs at the beginning; in 2016, the Taoxichuan Ceramic Cultural and Creative Park built by the Jingdezhen municipal government gathered the international community and began to play a role in the popularization of ceramic art education; the Sanbao International Pottery Village, which began in 1995, is a venue for ceramic art seminars, exchanges and leisure travel, which is also one of the windows for the international exchange of ceramic culture in Jingdezhen.

\section{B. College education}

Since the 1980s, colleges and universities have popularized the modern ceramic art education system, and they are mostly the ideas introduced from the West. They use modeling ceramic art as the main means of communication and rarely involve in the general education of household ceramic art. It was only in the late 1980s that China began to set up independent ceramic art majors in major art academies across the country, but the educational concept, system and curriculum were all focused on the performance of 
modeling ceramic art. Taking Jingdezhen Ceramic Institute as an example, as a specialized ceramic university, the major it sets currently only differentiates ceramic design and ceramic art. There is no specific independent course direction for household ceramics research, only a few of the modules are covered in the course.

\section{Market}

The Chinese market is a market with special conditions in China that is different from foreign markets. For example, the ceramic market is mainly formed in the Lotte, Taoxichuan and Ming and Qing Gardens in Jingdezhen. Operators of craft shops and pottery shops across the country, as well as people in the food and hotel and porcelain industries, form purchases or customizations at the fair. According to the survey of these three markets, the demand for pottery and porcelain utensils increased last year. From the sales trend of porcelain plates, vases and tea sets a few years ago, it began to be transformed into daily utensils such as bowls, plates and cups for daily life. However, this market has not become standardized, and many problems have begun to appear. Lotte, one of these markets, is due to the selection of cutting-edge ceramic artists, each has its own characteristics and is relatively stable. However, the low-price or cheap travel products formed by the Ming and Qing Gardens or Taoxichuan subsequently formed price competition. Because the cost of the price was low and the quality was reduced, there was no new development. Therefore, the author believes that potters need to raise market awareness and also need some systematic management. It is difficult to form a good market price atmosphere for this kind of Jingdezhen market. It has drawbacks. In contrast to this, online sales platforms have formed operating models such as Taobao, Microstore such as Yitiao, Wudao and other brands; ceramic shops are directly operated by small-brand artists to produce and sale on their own.

\section{Chinese household ceramic art potters}

The artists engaged in household ceramic art in China have just started in the 1990s, and currently $80 \%$ are young artists graduating from various universities. Their age level is generally under 40 years old. There are few household ceramic art potters with certain research ability and right to speak.

\section{JADE CAN BE POLISHED BY STONES FROM OTHER HILLS: ASPECTS THAT NEED TO BE CORRECTED AND INVESTED IN THE DEVELOPMENT OF CHINESE HOUSEHOLD POTTERY IN THE FUTURE}

By comparison, it is not difficult to find that the enlightenment of the entire modern ceramic art in
Korea is about 30 years earlier than that of China. China began the enlightenment of modern ceramic art in the 1980s, while Korea began the enlightenment of modern ceramic art in the 1950s. As two countries in the Asia-Pacific region, Korea's ceramic art has the same strain as China. Their development path and problems encountered are so similar to China, so through them, the direction China needs to learn from the development of household ceramic art can be seen.

After the national material level reaches a certain height, the pursuit of spiritual needs is inevitable. The author has been participating in various national fairs five or six years ago. Especially in recent years, the author have been able to feel the obvious changes. The public's interest in pottery art has increased significantly. Some excellent household ceramic works in the expo always get a lot of attention. However, at present, there are relatively few artists engaged in the study of household ceramics and having a certain degree of aesthetics and production. Most of them are young and middle-aged students who have just graduated from university for about five years. Artists engaged in household ceramics do not yet have three generations of old, middle-aged and young. At present, teachers in art colleges in major universities are mostly ceramic artists who study plastic arts. There is little research on the market and value of household ceramics. The accumulation of household ceramic art is the same as other modern ceramic art of modeling. It takes a long time to personally produce and devote time to research to reach a certain height. Although many of the current young ceramic artists are excellent ceramic artists, but the time they are engaged in is still short, and all aspects need to be experienced. This is a lot of the shortcomings of the artists who are currently engaged in household ceramic art.

In college education, many people have questions about the professional education courses of modern ceramic art, especially the courses of universities. The conscious and basic potters trained under the current education system can't play a practical role with specialized skills in the industrial field. This requires schools to reform the traditional teaching curriculum and let students have more contact with the market to understand the current environment. It is an important task for future curriculum reforms to enable students to learn more comprehensively in the classroom so that they can independently meet the needs of the pottery production process. In the future, it is hoped that more teachers from colleges and universities will be able to invest more in the creation and research of pottery household ceramic art. Their personally physical actions can play a role like one will be worth a hundred. The potters have to return to the creative world where art has labor and sweat. The art, especially ceramic art, has more practical and labor-like product characteristics than the art on the shelf. As a potter, the connection 
with his work and working with the soil can gradually establish the aesthetic consciousness of pottery. Only in the practical actions of labor and sweat can the ceramic artist be resurrected, which is a necessary process to restore and carry forward the spirit of the craftsman.

In particular, the government must also play a key role in the development of contemporary ceramics. The government must set up a special research institute on the viewpoint of the development of living ceramic art and the inheritance of traditional culture. However, the existing folk museums and modern art galleries of ceramic art lack a museum that can be connected to the same place as the past and modern times. Ceramic craftsmanship should be carried out together with indepth understanding and thorough research of all parts of society and nature. At present, the government has not invested too much experience in household ceramic art or mass art, nor does it have a certain institution or cultural research institute to study the current trend of household ceramic art. There are no large-scale exhibitions on life-style ceramics or competitions that distinguish plastic arts from life-style ceramics in national exhibitions.

As far as the market is concerned, there are currently only a few specialty shops specializing in household pottery works, and all of them are exhibited in a small range of individual pottery artists in the circle. There are still no specialized galleries or buyers who have a certain aesthetic ability to household pottery art. Most household ceramic art potters fight alone, and there is no certain group. Several Chinese life-related ceramic art shops have appeared in China, including Shanghai's Mansheng Kuaihuo, Pu, Bowl Store, Changle and Spin Xuan, Hangzhou's Hexia Taoshe, Nanjing's Heguang Taoshe and Shenzhen's Duiwei. The publicity media for ceramics on the Internet include the Zuitaoci, Ciwa and Weizhi Taoshe. But as far as the entire market is concerned, the popularity is still limited.

\section{CONCLUSION}

Looking at the development and maturity of household ceramics in Korea, it is not difficult to find out that China is currently in a situation similar to that of Korea in its development, and the problems it faces are also similar. With the stability of China, the prosperity of society, and the gradual improvement of people's living standards, the public's demand for household ceramics will continue to increase. In the face of a great external situation, there is an urgent need for the government and school educational institutions to help form a good ecological environment and enable household ceramics get good development.

\section{References}

[1] Li Lingmei. The status quo of Korean pottery art [J] .Journal of Nanjing Art Institute, Fine Arts and Design Edition. 2011, No.3: (25-30) (in Chinese)

[2] Huang Sheng. On the reform of the combination of household ceramic art teaching and market $[\mathrm{J}]$. Art Education. 2006, No.11: (56) (in Chinese)

[3] Yu Hong. Exploring the creation of household pottery in the context of contemporary culture [J]. Foshan Ceramics. 2017, No.4: (38-40) (in Chinese)

[4] Liu Zongyue (Japanese). Translated by Xu Yiyi. Technology Culture. Guangxi Normal University Press 2006. (in Chinese)

[5] Cui Zhiying; A Comparative Study of Alternative Cultures in Japan and South Korea [J]. Contemporary Asia-Pacific Studies; 2005-05. (in Chinese)

[6] Guo Hang; Express Themselves with Utensils -Korean and Japanese Porcelain Utensil Artists [J]. Sculpture. 2005-02. (in Chinese) 